\title{
Impact of Self Expressive Brands and Brand Attachment on Brand Advocacy: The Mediating Role of Brand Love
}

\author{
Abdul Qayyum ${ }^{1}$, Ayesha Saeed ${ }^{2}$, \\ 1,2Riphah International University, Islamabad, Pakistan
}

\begin{abstract}
The main objective of this study was to examine the impact of self expressive brands and brand attachment on brand advocacy with the mediating role of brand love. Findings are revealed on the survey of people who get involved with the Clothing Brand and become brand advocates. Hypotheses were tested with a sample of 275 respondents and the regression analysis was conducted to test the hypotheses. The results of the study show the partial mediating impact of brand love on the relationship between self expressive brands and brand advocacy, while full mediation impact of brand love on brand attachment and brand advocacy relationship has been observed. This research project highlights that brand love needs to be created along with brand attachment in customers mind so as to make them brand advocates. The findings of this research will help the marketer for implementing better marketing techniques to make their brand more strong and recognizable among customers.

Key words: Self Expressive Brands, Brand Attachment, Brand Love, Brand Advocacy, Clothing Brand
\end{abstract}

\section{Introduction}

In the recent years, the marketers came to realize that the customer's experience, feedback and reviews are significant determinants for developing marketing strategies (Chattopadhyay and Laborie, 2005). So, they push the customers towards WOM behavior through direct interaction with customers (Wragg, 2004). During the past few decades, the researchers started paying attention to the concept of love (Hatfield and Sprecher, 1986). Because of the familiar and favorable signal that a brand sends, consumers buy the brand with more comfort, believing that the brand will meet their expectations (Kim et al., 2008). The consumers show greater love and attachment for brands that reflect their inner self as well as their social self (Carroll and Ahuvia, 2006). Consequently, their purchase decisions are mainly based on the symbolic meanings of a product, which is used to create and maintain self identity (Fournier, 1998). Such type of brand identification with oneself helps in creating positive feeling towards a specific brand called brand love (Hwang and Kandampully, 2012). For a brand love, the consumers are required to be attached to that brand so as to feel that if that brand is missed or matchless, they don't have the same brand (Hazen and Shaver, 1987). The concept of attachment was first taken from the attachment theory of psychology. Later on different authors have studied this with diverse perspectives as interpersonal relationships (Bowlby, 2012). According to Bergkvist and

\footnotetext{
${ }^{1}$ Corresponding author.

Email: abdul.qayyum@riphah.edu.pk
}

Bech-Larsen (2010), the consumers who have strong brand identification experience have more brand love and active engagement. People give positive comments about a brand and sometimes recommend it to others; it is asserted that brand advocates are also likely to accept new brand extensions and to forgive a brand for wrongdoing (Du et al., 2007).

Nowadays, consumers are facing uncertainty about brand attributes because of too much clutter of brands in the competitive market environment (Cătălin and Andreea, 2014). By choosing a specific brand, an individual may obtain personal identity as well as social identity in the society (Fournier, 1998). During the past few decades, only few researchers have examined the relationship of brand advocacy and brand choice. The previous research revealed that the higher level of brand advocacy enhances the chances of brand to be included in consideration set (Erdem and Swait, 2001). This research study extends previous work on brand advocacy and it will provide a good insight into the application of branding theory through consumerobject relationships. Furthermore, managerial implications for developing effective brand management system that appeal to customers will also be highlighted in this study (Sheeraz et al., 2012).

Creating the customer engagement is considered as an important business practice for establishing sustainable competitive advantage, so as to predict the future business performance (Brodie et al., 2013). The concept helps the firm in maintaining long term consumer- 
brand relationships, which states that customers form relationship with the brands which they like the most (Fournier, 1998). The customer engagement is desired by the marketers because it leads to sales growth and also enhances the firm's profitability (Sashi, 2012). The marketers should position the brands according to the consumer's preference and lifestyle (Cătălin and Andreea, 2014). The results of the study are beneficial for brand managers as they can use different marketing tools to make their brand more strong and recognizable for increased profits (Sheeraz et al., 2012).

This study has considerable importance from managerial aspect as it would indicate that if brand love influences the customer's perception towards a certain brand in a positive way and affect their purchase intension through the effect of positive word of mouth, then the firm should create the feeling of love by communicating the right message about the brand that is relevant to customers' identity and encourage them to "express yourself" through association with the brand (Hwang and Kandampully, 2012). Furthermore, the aim of the study is to add more knowledge to the existing literature on brand advocacy specifically in clothing industry.

\section{Literature Review}

\subsection{Brand Advocacy}

During the past few decades, the academic society and practitioners have started paying attention to the concept of brand advocacy. The customers consider advocacy as an influential source of information, because it is derived from a less biased source (Herr et al., 1991). When a customer makes connection with a particular brand, the connection leads him to advocacy as the customer willingly spreads positive WOM about the brand (Anderson, 1998). Du et al. (2007) defined the brand advocacy as "to accept new brand extensions and to forgive a brand for wrongdoing". According to Harrison-Walker (2001) the customer's commitment with a brand and the quality of service motivates the customers to advocate the brand among others. Brand advocacy is one form of value creation. The two dimensions of brand advocacy are words of mouth and brand acceptance (Wallace et al., 2014). Words of Mouth advocacy is considered as an important tool for brand development. It can be defined as the process of sharing information and opinions about a particular product or service among customers (Jalilvand et al., 2011). Words of mouth are created from friends, relatives, professionals and experts, etc (Senecal and Nantel, 2004). Whenever the company introduces new product, the customers accept the brand, recommend this to others and forget the wrongdoing of brand (Du et al., 2007).

\subsection{Self Expressive Brands and Brand Ad- vocacy}

Self expressive brand refers to a perception that how well a particular brand will communicate the person's inner self and boost his/her social self. By obtaining a specific brand, people tend to express to others what kind of personality they have (Georgescu et al., 2011). An individual present his/her likeable image through a specific brand. For example, a young girl may wear branded dress as to show that she is cool and stylish (Aaker, 2010). Self expressive brands persuade the consumer to accept the brand, develop bond of affection, become loyal and spread positive WOM about the brand (Carroll and Ahuvia, 2006). As self expressive brands have the ability to express customer's inner self, as well as social self among others therefore, the brand must have a clear and distinguish image that allow customers to show their personal identity to others (Karjaluoto et al., 2016).

Many research studies have been conducted to investigate the impact of brand advocacy on consumer behavior. When a consumer receives consistent positive WOM about a brand, then he or she shows stronger intention to purchase that brand (Mazzarol et al., 2007). Wallace et al. (2014) investigated the impact of selfexpressive brands on brand advocacy and stated that the customers like the brand that expresses their social selves to others and have high probability to accept new product from the same brand and forget the wrongdoing. The consumer develops strong bond and connectedness with a particular brand and tries to maintain long lasting relationship with the brand by spreading positive words of mouth about the brand and accepting its wrongdoing. Because the brand develops symbolic significance to consumer and become part of his personal identity, self image, and self esteem. The relationship leads the customers to brand advocacy (Rageh Ismail and Spinelli, 2012). So it can be hypothesized that:

$H_{1}$ : Self-Expressive Brands have positive impact on Brand Advocacy.

\subsection{Brand Attachment and Brand Advocacy}

In recent years, the brand attachment gained the importance in marketing. Attachment is the set of emotional and cognitive schemas that are used by consumers to create a relationship to connect themselves with the brand (Thomson et al., 2005). According to Batra et al. (2012) attachment is an emotional connection between a person and a brand. In attachment process, the consumers feel attachment to a particular brand, think that the brand is matchless, and miss the brand when the brand is not available to them (Park et al., 2006). Brand attachment creates emotional asso- 
ciation with a brand. This emotional attachment can be strengthened by three factors i.e., customer's association with a brand, affection with a brand and a feeling of strong liking towards a brand (Thomson et al., 2005). The attachment feelings that a consumers develop for a particular brand are the same as they develop attachment in their interpersonal relationships (Baldwin et al., 1996). Consumer with strong attachment to a brand is more willing to maintain long term relationship with the brand and produce positive word of mouth about the brand (Whan Park et al., 2010).

The concept of attachment was first taken from the attachment theory of psychology (Bowlby, 2012). This theory explained the deep attachment formed by the infants with caregivers. When this theory is applied to consumer brand relationship, the attachment to a brand is based on trust and consistency of response. The customer feels attachment to a brand, which is consistent and always available, maintain relationship with that brand and become brand advocate. For instance, a consumer decides to wear Hollister Brand because she feels emotional attachment with that brand. This feeling of attachment describes a strong bond of affection between the consumer and the brand (Kleine et al., 1995). After using that brand she will produce positive statements and spread positive Word of Mouth about the brand in her social circle. Hence, the customer's perception of attachment with a particular brand promotes the advocacy of that brand (Lee and Workman, 2015). Therefore, it is expected that:

$\mathrm{H}_{2}$ : Brand Attachment has positive impact on Brand Advocacy.

\subsection{Self Expressive Brands and Brand Love}

Ahuvia (2005) identified that the self expressive brands help to extend ones' 'self '. When a brand provides something imperative to a customer, they make this brand as part of their identity and include it in their social life (Goldsmith, 2009). Because the consumers are now aware that the brand is not only linked with their lifestyle, goals and values but also it is used to express those values to other people (Berger and Heath, 2007). The favorable characteristic of a brand helps in creating customer's self-connection and therefore leads to intense love and commitment to the brand that keeps the consumer with the brand and encourages him to become a brand lover (Loureiro et al., 2012). Based on cognitive perception, males are more loyal with a brand than females; as men require detailed information about a particular brand or product because of its technicality. So the company should provide specific information about the brand to its customers (Pandir and Yasin, 2017).

Fournier and Mick (1999) identified brand love as a sort of satisfaction and explained that a satisfied cus- tomer becomes emotionally attached to a brand and thus willingly declares love to that brand because the brand is incorporated in his/her identity. According to Aaker (2010) self-expressive brands develop a strong relationship between consumer and the brand. Aggarwal (2004) proposed that consumer makes relationship with brands as they consider them as relationship partners so they show stronger feeling of love and affection for that brand, which gives social identity and self confidence to them and hence this feeling of self confidence motivates them to show stronger love and affection towards that brand (Carroll and Ahuvia, 2006). So it is hypothesized that:

$\mathrm{H}_{3}$ : Self Expressive Brands have positive impact on Brand Love.

\subsection{Brand Attachment and Brand Love}

Many researchers have widely accepted that attachment is the element of brand love (Loureiro et al., 2012). According to Lee and Workman (2015) brand attachment develops strong brand loyalty among customers. The brand attachment creates feeling of love to a brand, helps to develop interest and to maintain the relationship with the brand in future. A consumer develops strong affective and cognitive perception of brand in his mind, which creates feelings of attachment with the brand Fournier (1998). There is a positive impact of brand attachment on brand love feeling. This feeling motivates the consumers to strengthen the trust on the brand as the interest in the brand leads to maintain long term relationship and develop feelings of love for that brand (Loureiro et al., 2012).

The emotional attachment develop strong relationship between customer and the brand, develops positive feeling for the brand and thus leads to brand love (Loureiro et al., 2012). The researchers had found that the psychological attachment to a brand encourages a customer to show willingness to obtain the brand. A consumer who is emotionally attached to a brand feels love towards with the brand, shows repeat purchase intention, spends resources (e.g., money, time and efforts) to obtain that brand and hence leading to brand loyalty (Lee and Workman, 2015). The attachment can be formed on the basis of relationship between an individual and a brand. For instance, the customers form attachment with luxury brands as the brands help the customers to enhance their classic image (Park et al., 2006). The consumer with positive experience of a brand feels strong emotional attachment to that brand and that emotional attachment leads to brand love (Carroll and Ahuvia, 2006). It is hypothesized that:

$\mathrm{H}_{4}$ : Brand Attachment has a positive impact on Brand Love. 


\subsection{Brand Love and Brand Advocacy}

According to (Fournier, 1998) love is a core element between consumer-brand relationships. The feeling of love may occur when a consumer possessed love towards a particular brand (Aaker, 1997). The relationship of brand love is deep, long lasting and is considered as irreplaceable (Albert and Merunka, 2013). Brand love motivates the customer to produce positive Words of Mouth about the brand (Batra et al., 2012). According to Pandir and Yasin (2017), if customer buys a brand at least once in two weeks, the feeling of love will be stronger. So, the loyal customers have higher probability to spread positive Words of Mouth (Bowman and Narayandas, 2001). Because the customers feel love towards the brand that they consider relevant with their inner self and social self (Cătălin and Andreea, 2014) and thus, brand love encourages the customers to spread positive words of mouth about the brand. So the customers produce positive views about the brand and maintain long lasting relationship with it (Albert and Merunka, 2013).

During the past few decades, different researchers have identified different love styles (Albert et al., 2008). Carroll and Ahuvia (2006) found the positive impact of brand love on word of mouth behaviour. When the satisfaction level of customer increases by experiencing a brand, s/he may spread positive opinion about the brand (Anderson, 1998). Brand passion is positively associated with evangelism, where people produce positive WOM about the brand and persuade others to make association with the same brand (Matzler et al., 2007). Biçakcioğlu et al. (2018) revealed that brand love is a powerful source of word of mouth communication, which states that stronger feeling of love encourage customers to spread positive words of mouth about a brand among their family, friends etc. So it is expected that:

$H_{5}$ : Brand Love has a positive impact on Brand Advocacy.

\subsection{Mediating role of Brand Love}

Carroll and Ahuvia (2006) stated that the brands which are more likely to enhance customer's identity have stronger affecting responses and hence create brand advocacy. When the people get involved with the brand, they feel love towards that brand, become brand advocates and produce positive word of mouth about the brand (Wragg, 2004). An individual may develop strong connection with the brand so to satisfy his/her psychological needs, to show identity and to make connection with others (Wallendorf and Arnould, 1988). Although the concept of eWOM is growing day by day, but the consumers consider traditional word of mouth more secure and safe for sharing their views about the product (Karjaluoto et al., 2016). The WOM behavior is affected by the nature of selfexpressive brand. If the brand is more self-expressive, the consumer will strongly engage in positive words of mouth. Because people want to make connection with brands so to feel sense of love for them. So, when a brand meets with both the actual and desired integration level of customer and enhances his or her sense of self, the person feels love for that brand and becomes brand advocate (Carroll \& Ahuvia, 2006).

According to Bergkvist and Bech-Larsen (2010) customers who have a stronger bond of affection with the brand express more brand love, and produce positive WOM about the brand (Wragg, 2004). The attachment shows the behavioral intention of the customer that how a customer responses to a specific brand. So, a customer with strong brand attachment will use emotional, cognitive and financial resources to obtain that brand (Fedorikhin et al., 2008). The customers with emotional attachment with a brand become active brand advocates and make the brand active through higher level of involvement and word of mouth. The marketers can forecast the number of actual purchase of the brand, brand attitude, brand need and the purchase share of the brand through brand attachment (Whan Park et al., 2010). The strong attachment to a brand increases the brand loyalty among customers and they are ready to pay price premium. The customer's emotional attachment to a brand results in brand love, brand connection and brand affection and thus, consumer with strong brand attachment is more committed to the brand and maintain long term relationship with the firm (Thomson et al., 2005). So it is hypothesized that:

$H_{6}$ : Brand Love mediates the positive relationship between Self-Expressive Brands and Brand Advocacy.

$H_{7}$ : Brand Love mediates the positive relationship between Brand Attachment and Brand Advocacy.

Based on the above relationships between variables, the following framework is developed:

\subsection{Interpersonal relationship theory}

Triangular theory of interpersonal relationship is proposed by Sternberg (1986) in which he explained the interpersonal relationship among the three fundamental components of love (i.e., intimacy, passion, and decision/commitment). The theory states that a consumer develops strong bond and connectedness with a particular brand and tries to maintain love throughout his life because the brand develops symbolic meaning to consumer and becomes a part of his personal identity (Fournier, 1998). This feeling of love and attachment with the brand persuades him to produce positive 


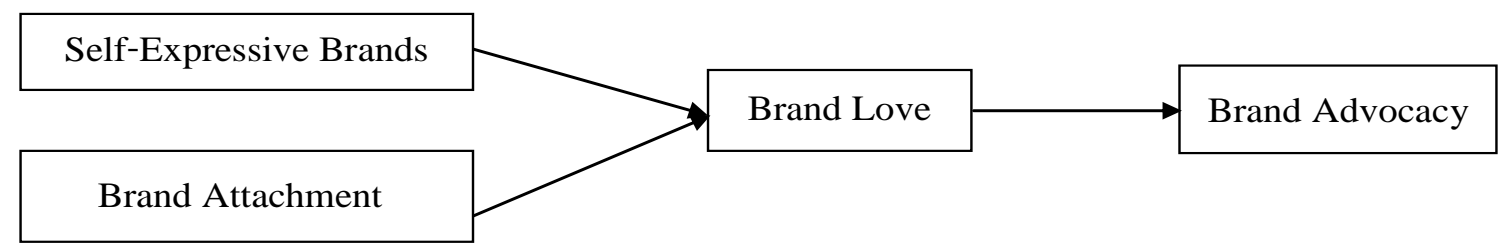

Figure 1: Research Model

statements about that brand (Ahuvia, 2005). The relationship strength is based on the combination of any of these three components which leads to brand advocacy (Rageh Ismail and Spinelli, 2012).

\section{Methodology}

\subsection{Sample and Procedure}

To figure out the impact of self expressive brands and brand attachment on brand advocacy with the mediating role of brand love, the primary data have to be collected. The population of the study includes the customers of Rawalpindi and Islamabad who used to wear branded clothes. The data were collected from both the male and female customers. The quantitative approach was used to focus on solving the problem under study. As the sampling framework was not available so the convenience sampling technique was used to collect data from the respondents within a given time period.

In the data collection process, self administered questionnaire was used to collect data about variables of the theoretical framework. $24.4 \%$ respondents were males and $75.6 \%$ were females. Most of customers belong to age group of $21-30$ years. There were $85.1 \%$ customers who belong to age group of $21-30$ years, $8.4 \%$ were from age group of Below 20 years, $4 \%$ were from age group of $31-40$ years while $2.5 \%$ were from age group of 41 and above. The data were gathered from students, housewives and job holders who mentioned their favourite clothing brands. There were $70.18 \%$ students, $8 \%$ housewives, $18.55 \%$ doing job in public and private sector while $3.27 \%$ were running their own independent business. Total 300 questionnaires were distributed, out of which 283 were given back by the respondents. There were 8 questionnaires in which data were missing. Thus 275 questionnaires were used for data analysis and the response rate was $92 \%$.

\subsection{Scales and Measures}

The eight items of Self Expressive Brands were adopted from Carroll and Ahuvia (2006) and measured on 5-point Likert scale. First sample item was "This clothing brand symbolizes the kind of person I really am inside". Brand Attachment was measured on 5- point Likert scale with three items that were adopted from Fournier (1998); Chang and Chieng (2006) and Thomson et al. (2005). The item includes "No other clothing brand can take the place of this brand". To measure Brand Love, ten items that were adopted from Carroll and Ahuvia (2006) and measured on 5- point Likert scale. The sample item of Brand Love was "This is a wonderful clothing brand". Brand Advocacy was measured using five items. It contains two dimensions: WOM ( 3 items) and Brand acceptance ( 2 items). The items of word of mouth were adopted from Unal and Aydin (2013) while items of brand acceptance were adopted from Carroll and Ahuvia (2006); \& Du et al. (2007). The items were measured on 5- point Likert scales. First item was "I recommend this brand to many people". SPSS software was used for data analysis. The population parameters are estimated through sample statistics and simple Linear Regression was run to test the hypothesis.

\section{Results}

Table 4.1: Reliability Analysis

\begin{tabular}{lcc}
\hline Variables & No of items & Alpha \\
\hline Self Expressive Brands & 8 & 0.876 \\
Brand Attachment & 3 & 0.797 \\
Brand Love & 8 & 0.811 \\
Brand Advocacy & 5 & 0.779 \\
\hline
\end{tabular}

For good reliability, the value of Cronbach's alpha should be in the range of $0.7-1$. Table 4.1 presented above shows that the Cronbach's alpha for self expressive brands 0.876 , brand attachment is 0.797 , brand love is 0.811 and brand advocacy is 0.779 . Hence, the questionnaire is considered as reliable for further research analysis.

\subsection{Correlation Matrix}

Table 4.2 shows the correlation among the variables. The results indicate that self expressive brand and brand attachment are positively and significantly correlated at $0.5252^{* *}(r=0.587)$. Similarly, self expressive brand is also positvely correlated with brand love 
Table 4.2: Means, Standard Deviations, Correlations \& Reliabilities

\begin{tabular}{lcccccc}
\hline Variables & Mean & S.D & SEB & B.ATT & BL & B.ADV \\
\hline Self Expressive Brands & 2.237 & 0.658 & 1 & & & \\
Brand Attachment & 2.521 & 0.845 & $0.525^{* *}$ & 1 & & \\
Brand Love & 2.132 & 0.576 & $0.624^{* *}$ & $0.587^{* *}$ & 1 & \\
Brand Advocacy & 2.146 & 0.558 & $0.529^{* *}$ & $0.457^{* *}$ & $0.688^{* *}$ & 1 \\
\hline
\end{tabular}

**. Correlation is significant at the 0.01 (99\%) level (2-tailed).

and brand advocacy with $\mathrm{p}$ at $0.624^{* *}$ and $0.529^{* *}$ respectively. Brand Love has strong positive impact on Brand Advocacy $\left(r=0.688\right.$, value of $\left.\mathrm{P}=0.01^{* *}\right)$ and Brand Attachment also has positive impact on Brand Advocacy at $\left(\mathrm{r}=0.475, \mathrm{P}=0.01^{* *}\right)$. The correlation values are less than 0.8 which shows that none of the variable is highly correlated and all the variables are significant at $99 \%$ confidence interval. Therefore, it provides initial support for all hypotheses. As all the variables have value less than 0.8 hence they all are considered as a separate construct.

\subsection{Regression Analysis}

Table 4.3 shows the results from regression analysis of mediation effect of brand love on the relationship between self expressive brands and brand advocacy and brand attachment and brand advocacy. To test the mediation analysis regression was run based on Preacher and Hayes model 4. The results shows that the self expressive brands has significant positive influence on brand love $(\beta=0.546, \mathrm{p}<0.05)$ and brand advocacy $(\beta$ $=0.138, \mathrm{p}<0.05)$. Brand attachment has a positive and a significant effect on brand love $(\beta=0.400, \mathrm{p}<0.05)$ while nonsignificant effect on brand advocacy with $(\beta$ $=0.053, \mathrm{p}>0.05)$. Brand love has significant impact on brand advocacy with $(\beta=0.568, \mathrm{p}<0.05)$. The effect size for both the mediation hypotheses with a $95 \%$ confidence interval was ( $\beta=0.310, \mathrm{CI}: 0.200$ to 0.429 ) and ( $\beta=0.248, \mathrm{CI}: 0.152$ to 0.340$)$ respectively. Since the $95 \%$ confidence interval does not contain zero it shows that the indirect effect is significant and the mediation is supported. So, it indicates that brand love partially mediates the relationship of self expressive brands and brand advocacy and fully mediates the relationship of brand attachment and brand advocacy. Therefore, the proposed hypotheses are accepted and proven to be true.

\section{Discussion}

The purpose of this study was to explore the impact of self-expressive brands and brand attachment on brand advocacy in the presence of brand love. The findings of this research are helpful starting point for future research, and provide managers the key to gain more customers attention through brand advocacy. The findings of first hypothesis showed that self expressive brand has positive impact on brand advocacy. The result is consistent with the proposed hypothesis and is similar to the results of Batra et al. (2012). Previous researches also identified the positive relationship between self expressive brands and brand advocacy. Wallace et al. (2014) revealed that the customers want to show others that what kind of personality they have so they prefer the brand which expresses their social selves among others and thus they have a high probability to accept new product from the same brand, produce positive words of mouth about it and forget the wrongdoing.

Brand attachment was found to have positive impact on brand advocacy. This is because, the brand attachment creates positive feeling towards a brand that

Table 4.3: Regression Analysis

\begin{tabular}{lllcccccc}
\hline Predictor & \multicolumn{1}{c}{ Outcomes } \\
\hline & \multicolumn{3}{c}{ Brand Love } & \multicolumn{4}{c}{ Brand Advocacy } \\
\hline Direct Effects & $\beta$ & SE & $\mathbf{t}$ & $\mathbf{p}$ & $\beta$ & SE & $\mathbf{t}$ & $\mathbf{p}$ \\
\hline Self Expressive Brands & $.546^{* *}$ & .041 & 13.198 & .000 & $.138^{* *}$ & .047 & 2.943 & .004 \\
Brand Attachment & $.400^{* *}$ & .033 & 11.975 & .000 & .053 & .036 & 1.483 & .139 \\
Brand Love & & & & & $.0568^{* *}$ & .054 & 10.583 & .000 \\
\hline Indirect effects & & & & $\beta$ & SE & LLCI & ULCI \\
\hline Brand Love & & & & & .310 & .059 & .200 & .429 \\
& & & & & .248 & .049 & .152 & .340 \\
\hline
\end{tabular}

${ }^{*} p=0.10,{ }^{* *} p=0.05,{ }^{* * *} p=0.001 ;$ ns $=$ not significant 
helps to develop interest in that brand and encourages maintaining the relationship with the brand in future and thus, the customers present favorable statement for a particular brand that can enhance the brand adoption and acceptance and become the brand advocate Keller (1993). Similarly, it was hypothesized that there is positive impact of self-expressive brands on brand love. The result of this hypothesis is in line with the previous study of Carroll and Ahuvia (2006). The customers create strong brand connection with a brand that is unique in nature. Because the customers consider that the brand has the ability to express their identity among their friends, relatives and peers (Kim \& Aimee, 2003). So they show strong love for the brands that helps them in determining their social self as well as their ideal self (Carroll and Ahuvia, 2006).

The relationship between brand attachment and brand love is also significant and the result is corresponding to the study of Loureiro et al. (2012). According to previous researches, consumers have strong feeling of attachment with their love objects (Fournier and Mick, 1999). The consumer with positive experience of a brand feels strong emotional attachment to that brand and that emotional attachment leads to brand love (Carroll and Ahuvia, 2006). Hence it is proved that there is positive impact of brand attachment on brand love. Moreover, brand love is found to have a positive impact on Brand Advocacy. This hypothesis is also accepted and the result is similar to the study of Bergkvist and Bech-Larsen (2010). Thomson et al. (2005) stated that brand love motivates the customers to develop strong connection with their favorite brand. This loved feeling encourages them to accept the brand and purchase it again and again. So, brand love leads them to greater brand loyalty, and thus, the customer produces positive words of mouth about that brand and develops long lasting relationship with it (Lee \& Workman, 2015).

The findings of hypothesis revealed that self expressive brands help in creating brand love which ultimately encourages the customers to become brand advocate. The result is similar to the findings of $\mathrm{Du}$ et al. (2007) and Wallace et al. (2014). According to Batra et al. (2012) the customers express their identity through their loved brand among others. As, self expressive brands help the customer in creating brand love. Thus, the feeling of love towards a brand leads towards brand advocacy (Du et al., 2007). So the self expressive brand has direct and positive impact on brand love and brand love mediates the relationship between self expressive brand and brand advocacy (Wallace et al., 2014). Similarly, the hypothesis that brand attachment has positive impact on brand advocacy in the presence of brand love is also accepted. The relationship of brand attachment and brand advocacy is fully mediated by brand love and this result is in line with past study of Carroll and Ahuvia (2006) and Loureiro et al. (2012). According to Loureiro et al. (2012) brand attachment has greater positive impact on brand love than self expressive brands. The strong brand attachment motivates the customer to maintain long lasting relationship with the brand and thus the customer shows willingness to pay for that brand. So it is concluded that strong brand attachment increases the brand loyalty among customers and push them to pay price premium (Thomson et al., 2005).

\subsection{Practical Implications}

The results of the present study show that brand love has partial mediating effect on the relationship between self expressive brands and brand advocacy and full mediating effect on the relationship between brand attachment and brand advocacy. So both the local and corporate managers can build the brand identity by communicating the message about the brand that is relevant to customers' identity (Loureiro et al., 2012). The positive influence of self expressive brands on brand love shows that the consumers show greater love to a brand which helps them to show their personal identity among others. Therefore, the managers should highlight the symbolic features of a brand so to leave positive and long lasting impression on customers, which will ultimately increase the customer's love for that brand (Biçakcioğlu et al., 2018). At the present time, this world became an emotional place where customer's decision making is greatly influenced by their feelings (Berry, 2000). Due to this reason, the managers must create emotional attachment between the consumers and brands (Levy and Hino, 2016), by introducing different promotional strategies so to attract the customer towards the brand. For instance, incentives program or family and friends programs, etc. help to keep the customer attached to the brand and thus feel emotional attachment to that brand (Lee and Workman, 2015). Furthermore, brand love is positively associated with brand advocacy so factors like brand quality, employee training could be considered to make sure that the customers' needs are fulfilled accordingly. This will make the customer more committed to the brand and will spread positive word of mouth about the brand. On the other hand, companies can also obtain some return on investment through such type of actions (Albert and Merunka, 2013).

\subsection{Limitations of Study}

There are few limitations of the study which were faced while conducting research process. First of all, the sample size for this research was very small (i.e., 275) due to which, the results of this research are not generalized at a large scale and are applicable only in the twin cities. Secondly, due to time constraint, convenience sampling was used to obtain customer's re- 
sponse which enhanced the biasness and produced narrow result. Sampling frame for this research was also not available due to which probability sampling technique could not be used. The variables such as brand hate, brand jealousy or other are not consider for defining brand love and a small sample was taken for the conducting the research accordingly. That is why, the study is not analyzed in detail and the dimensions of the variables are also not touched. There was also a financial constraint while conducting this research such as cost of printing, travelling and other expenditures.

\subsection{Directions for Future Research}

Some future research directions are provided to overcome the limitations of this study in order to explore the presented relationship more accurately. In future research, variables such as brand hate, brand jealousy brand trust should be taken as mediator in the model presented above. The dimensions of the variables should be study in order to get more precise result. The relationship of brand attachment and brand advocacy could be studied in future because the relationship is not thoroughly studied in previous researches. Further study should investigate the relationship between antecedents (consumer, brand or brand attributes etc) and brand love and which of the following have greater impact on brand love. Moreover, sampling technique other than convenient sampling should be used to get more appropriate results. In future, the research can be conducted in any other sector (e.g., footwear industry) and it will be interesting to consider different brands or product categories in the research context. Longitudinal research design can be used to avoid the common method biased. Sample size can also be increased to obtain the more accurate results.

\section{References}

Aaker, D. (2010). Marketing challenges in the next decade.

Aaker, J. L. (1997). Dimensions of brand personality. Journal of marketing research, pages 347-356.

Aggarwal, P. (2004). The effects of brand relationship norms on consumer attitudes and behavior. Journal of consumer research, 31(1):87-101.

Ahuvia, A. C. (2005). The love prototype revisited: A qualitative exploration of contemporary folk psychology. In University of Michigan-Dearborn Working Paper.

Albert, N. and Merunka, D. (2013). The role of brand love in consumer-brand relationships. Journal of Consumer Marketing, 30(3):258-266.

Albert, N., Merunka, D., and Valette-Florence, P. (2008). When consumers love their brands: Exploring the con- cept and its dimensions. Journal of Business research, 61(10):1062-1075.

Anderson, E. W. (1998). Customer satisfaction and word of mouth. Journal of service research, 1(1):5-17.

Baldwin, M. W., Keelan, J. P. R., Fehr, B., Enns, V., and KohRangarajoo, E. (1996). Social-cognitive conceptualization of attachment working models: Availability and accessibility effects. Journal of personality and social psychology, 71(1):94.

Batra, R., Ahuvia, A., and Bagozzi, R. P. (2012). Brand love. Journal of marketing, 76(2):1-16.

Berger, J. and Heath, C. (2007). Where consumers diverge from others: Identity signaling and product domains. Journal of Consumer Research, 34(2):121-134.

Bergkvist, L. and Bech-Larsen, T. (2010). Two studies of consequences and actionable antecedents of brand love. Journal of brand management, 17(7):504-518.

Berry, L. L. (2000). Cultivating service brand equity. Journal of the Academy of marketing Science, 28(1):128-137.

Biçakcıoğlu, N., İpek, İ., and Bayraktaroğlu, G. (2018). Antecedents and outcomes of brand love: the mediating role of brand loyalty. Journal of Marketing Communications, 24(8):863-877.

Bowlby, J. (2012). The making and breaking of affectional bonds. Routledge.

Bowman, D. and Narayandas, D. (2001). Managing customerinitiated contacts with manufacturers: The impact on share of category requirements and word-of-mouth behavior. Journal of marketing Research, 38(3):281-297.

Brodie, R. J., Ilic, A., Juric, B., and Hollebeek, L. (2013). Consumer engagement in a virtual brand community: An exploratory analysis. Journal of business research, 66(1):105114.

Carroll, B. A. and Ahuvia, A. C. (2006). Some antecedents and outcomes of brand love. Marketing letters, 17(2):79-89.

Cătălin, M. C. and Andreea, P. (2014). Brands as a mean of consumer self-expression and desired personal lifestyle. Procedia-Social and Behavioral Sciences, 109:103-107.

Chang, P.-L. and Chieng, M.-H. (2006). Building consumerbrand relationship: A cross-cultural experiential view. Psychology E Marketing, 23(11):927-959.

Chattopadhyay, A. and Laborie, J.-L. (2005). Managing brand experience: The market contact audit. Journal of Advertising Research, 45(1):9-16.

Du, S., Bhattacharya, C. B., and Sen, S. (2007). Reaping relational rewards from corporate social responsibility: The role of competitive positioning. International journal of research in marketing, 24(3):224-241.

Erdem, T. and Swait, J. (2001). Brand equity as a signaling. Journal of consumer Psychology, 7(2):131-157. 
Fedorikhin, A., Park, C. W., and Thomson, M. (2008). Beyond fit and attitude: The effect of emotional attachment on consumer responses to brand extensions. Journal of Consumer Psychology, 18(4):281-291.

Fournier, S. (1998). Consumers and their brands: Developing relationship theory in consumer research. Journal of consumer research, 24(4):343-373.

Fournier, S. and Mick, D. G. (1999). Rediscovering satisfaction. The Journal of Marketing, pages 5-23.

Georgescu, B., Nistoreanu, P., Anghel, L., Negoi, R., and Moise, D. (2011). Identifying the optimum price strategy of airlines companies for customer attraction and loyalty. Management of Technological Changes, pages 141-144.

Goldsmith, R. (2009). Conversational capital: How to create stuff people love to talk about. Journal of Consumer Marketing, 26(5):370-371.

Harrison-Walker, L. J. (2001). The measurement of wordof-mouth communication and an investigation of service quality and customer commitment as potential antecedents. Journal of service research, 4(1):60-75.

Hatfield, E. and Sprecher, S. (1986). Measuring passionate love in intimate relationships. Journal of adolescence, 9(4):383-410.

Hazen, C. and Shaver, P. (1987). Romantic love conceptualized as an attachment process. Journal of personality and social psychology, 52(3):511-524.

Herr, P. M., Kardes, F. R., and Kim, J. (1991). Effects of word-of-mouth and product-attribute information on persuasion: An accessibility-diagnosticity perspective. Journal of consumer research, 17(4):454-462.

Hwang, J. and Kandampully, J. (2012). The role of emotional aspects in younger consumer-brand relationships. Journal of Product $\mathcal{E}$ Brand Management, 21(2):98-108.

Jalilvand, M. R., Esfahani, S. S., and Samiei, N. (2011). Electronic word-of-mouth: Challenges and opportunities. Procedia Computer Science, 3:42-46.

Karjaluoto, H., Munnukka, J., and Kiuru, K. (2016). Brand love and positive word of mouth: the moderating effects of experience and price. Journal of Product \& Brand Management, 25(6):527-537.

Keller, K. L. (1993). Conceptualizing, measuring, and managing customer-based brand equity. the Journal of Marketing, pages 1-22.

Kim, J., Morris, J. D., and Swait, J. (2008). Antecedents of true brand loyalty. Journal of Advertising, 37(2):99-117.

Kleine, S. S., Kleine III, R. E., and Allen, C. T. (1995). How is a possession me or not me? characterizing types and an antecedent of material possession attachment. Journal of consumer research, 22(3):327-343.
Lee, S.-H. and Workman, J. E. (2015). Determinants of brand loyalty: self-construal, self-expressive brands, and brand attachment. International Journal of Fashion Design, Technology and Education, 8(1):12-20.

Levy, S. and Hino, H. (2016). Emotional brand attachment: a factor in customer-bank relationships. International Journal of Bank Marketing, 34(2):136-150.

Loureiro, S. M. C., Ruediger, K. H., and Demetris, V. (2012). Brand emotional connection and loyalty. Journal of Brand Management, 20(1):13-27.

Matzler, K., Pichler, E. A., and Hemetsberger, A. (2007). Who is spreading the word? the positive influence of extraversion on consumer passion and brand evangelism. Marketing Theory and Applications, 18(1):25-32.

Mazzarol, T., Sweeney, J. C., and Soutar, G. N. (2007). Conceptualizing word-of-mouth activity, triggers and conditions: an exploratory study. European Journal of Marketing, 41(11/12):1475-1494.

Pandir, B. and Yasin, B. (2017). Brand love and customer engagements role over brand loyalty. Journal of Management Marketing and Logistics, 4(4):359-365.

Park, C. W., MacInnis, D. J., and Priester, J. R. (2006). Beyond attitudes: Attachment and consumer behavior.

Rageh Ismail, A. and Spinelli, G. (2012). Effects of brand love, personality and image on word of mouth: The case of fashion brands among young consumers. Journal of Fashion Marketing and Management: An International Journal, 16(4):386-398.

Sashi, C. (2012). Customer engagement, buyer-seller relationships, and social media. Management decision, 50(2):253272.

Senecal, S. and Nantel, J. (2004). The influence of online product recommendations on consumers online choices. Journal of retailing, 80(2):159-169.

Sheeraz, M., Iqbal, N., and Ahmed, N. (2012). Impact of brand credibility and consumer values on consumer purchase intentions in pakistan. International Journal of Academic Research in Business and Social Sciences, 2(8):1.

Sternberg, R. J. (1986). A triangular theory of love. Psychological review, 93(2):119.

Thomson, M., MacInnis, D. J., and Whan Park, C. (2005). The ties that bind: Measuring the strength of consumers emotional attachments to brands. Journal of consumer psychology, 15(1):77-91.

Unal, S. and Aydin, H. (2013). An investigation on the evaluation of the factors affecting brand love. Procedia-Social and Behavioral Sciences, 92:76-85.

Wallace, E., Buil, I., and de Chernatony, L. (2014). Consumer engagement with self-expressive brands: brand love and wom outcomes. Journal of Product $\mathcal{E}$ Brand Management, 23(1):33-42. 
Wallendorf, M. and Arnould, E. J. (1988). my favorite things: A cross-cultural inquiry into object attachment, possessiveness, and social linkage. Journal of Consumer Research, 14(4):531-547.

Whan Park, C., MacInnis, D. J., Priester, J., Eisingerich, A. B., and Iacobucci, D. (2010). Brand attachment and brand at- titude strength: Conceptual and empirical differentiation of two critical brand equity drivers. Journal of marketing, 74(6):1-17.

Wragg, T. (2004). Nurturing brand advocates. Brand Strategy, 187:36-37. 